RISIKO KETERPAPARAN ROKOK TERHADAP BERAT PLASENTA RINGAN PADA IBU BERSALIN

\author{
Nia Rahmania ${ }^{1^{\star}}$, Riski $^{1}$, A.Fahira Nur ${ }^{2}$ \\ ${ }^{1}$ Mahasiswa Kebidanan STIKES Widya Nusantara Palu \\ ${ }^{2}$ Bagian Kebidanan STIKES Widya Nusantara Palu
}

*E-mail : rahmania.nia06@gmail.com

\begin{abstract}
Masalah kesehatan dipengaruhi oleh beberapa faktor, baik kesehatan individu maupun kesehatan masyarakat, beberapa faktor tersebut antara lain lingkungan, perilaku, serta pelayanan kesehatan. Beberapa faktor tersebut disamping berpengaruh langsung kepada kesehatan, juga saling berpengaruh satu sama lainnya. Status kesehatan akan tercapai secara optimal, bilamana faktor-faktor tersebut secara bersama-sama mempunyai kondisi yang optimal ${ }^{2}$.

Berikut ini penulis akan membahas tentang risiko keterpaparan rokok pada ibu hamil terhadap berat plasenta ringan.
\end{abstract}

\title{
1. Plasenta
}

Plasenta adalah organ yang sangat penting untuk menjaga kelangsungan kehamilan karena plasenta berperan untuk pertukaran $\mathrm{O}_{2}$ dan transfer nutrisi dalam pertumbuhan janin. Plasenta normal berbentuk ceper dan bulat, diameter $15-20 \mathrm{~cm}$ dan tebal $11 / 2-3 \mathrm{~cm}$, pada kehamilan cukup bulan, berat plasenta normal 500-600 gram ${ }^{2}$.

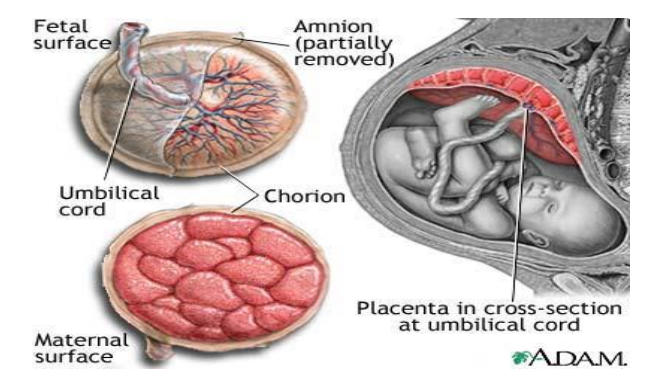

Gambar Permukaan Plasenta 
Plasenta berfungsi untuk nutritif, oksigenasi, ekskresi. Kapasitas pertumbuhan berat janin dipengaruhi oleh pertumbuhan plasenta dan terdapat korelasi kuat antara berat plasenta dengan berat badan lahir. Berat plasenta mencerminkan fungsi dan perkembangan plasenta itu sendiri dan berat plasenta juga dapat memprediksi kemungkinan terjadinya hipertensi dikemudian hari, sebaliknya plasenta ringan dapat mengindikasikan adanya kekurangan asupan nutrisi ke plasenta sehingga terjadi hipoksia plasenta yang pada akhirnya mengganggu fungsinya sehingga dapat berdampak pada bayi dengan Berat Badan Lahir Rendah (BBLR).

Kira-kira pada minggu ke-8 seluruh korion telah ditutup/ditumbuhi villi koriales. Dengan makin besarnya kantong ini, villi yang ada di seberang janin (pada daerah desidua kapularis) makin terjepit dan akhirnya mengalami degenerasi, sehingga daerah ini menjadi halus dan berkembang dengan cepat. Bagian korion ini disebut korion frondosum, yang akan membentuk plasenta (plasenta) dengan makin tumbuhnya villi, desidua basalis makin tererosi, sehingga terbentuk sekat-sekat yang disebut sekat plasenta. Sekat ini membagi plasenta pars fetalis menjadi kira-kira 15-30 lobuli yang disebut kotiledon. Tiap kotiledon berisi vilus utama dengan beberapa vilus cabang ${ }^{3}$.

\section{Kandungan Rokok}

Setiap rokok atau cerutu mengandung lebih dari 4.000 jenis bahan kimia, dan 400 dari bahan-bahan tersebut dapat meracuni tubuh, sedangkan 40 dari bahan tersebut bias menyebabkan kanker (Aula, 2010). Secara umum, bahan kimia ini dapat dibagi menjadi dua golongan besar yaitu komponen gas dan komponen padat atau partikel (Aditama, 1997).

Beberapa contoh zat berbahaya di dalam rokok yang perlu diketahui adalah sebagai berikut:

a. Nikotin

Nikotin adalah zat atau bahan senyawa pirolidin yang terdapat dalam Nicotiana tabacum, Nicotiana rustica, dan spesies lainnya 
yang bersifat adiktif dan dapat mengakibatkan ketergantungan. Nikotin menstimulasi otak untuk terus menambah jumlah nikotin yang dibutuhkan. Semakin lama, nikotin dapat melumpuhkan otak dan rasa, serta meningkatkan adnelain, yang menyebabkan jantung diberi peringatan atas reaksi hormonal yang membuatnya berdebar lebih cepat dan bekerja lebih keras. Artinya, jantung membutuhkan lebih banyak oksigen agar dapat terus memompa.

Secara perlahan, nikotin akan mengakibatkan perubahan pada sel-sel otak perokok yang menyebabkan seseorang merasa perlu merokok lebih banyak untuk mengatasi gejala-gejala ketagihan. Setiap batang rokok rata-rata mengandung 0,1-1,2 mg nikotin.

b. Karbon Monoksida

Karbon monoksida merupakan suatu komponen yang tidak berwarna, tidak berbau, dan tidak mempunyai rasa. Karbon monoksida yang terdapat di alam terbentuk dari proses pembakaran tidak lengkap terhadap karbon atau komponen yang mengandung karbon maupun reaksi antara karbon dioksida dan komponen yang mengandung karbon pada suhu tinggi (Fardiaz, 1992). Gas berbahaya pada asap rokok ini seperti yang ditemukan pada asap pembuangan mobil. Karbon monoksida menggantikan sekitar $15 \%$ jumlah oksigen, yang biasanya dibawa oleh sel darah merah, sehingga dapat mengurangi suplai oksigen pada jantung (Aula, 2010). Asap rokok mengandung $C O$ dengan konsentrasi lebih dari $20.000 \mathrm{ppm}$. Konsentrasi $\mathrm{CO}$ yang tinggi di dalam asap rokok yang terisap mengakibatkan kadar $\mathrm{COHb}$ di dalam darah meningkat. Selain berbahaya terhadap orang yang merokok, asap rokok yang mengandung $\mathrm{CO}$ juga berbahaya bagi orang yang berada di sekitarnya karena asap rokok dapat terhirup (Fardiaz, 1992).

c. Tar

Tar adalah kumpulan dari ratusan atau bahkan ribuan bahan kimia dalam komponen padat asap rokok setelah dikurangi nikotin 
dan air (Aditama, 1997). Tar digunakan untuk melapisi jalan atau aspal. Tar bukanlah zat tunggal, namun terdiri atas ratusan bahan kimia gelap dan lengket. Pada rokok atau cerutu, tar mengandung bahan kimia yang beracun, yang dapat merusak sel paru-paru dan menyebabkan kanker (Aula, 2010).

d. Arsenic

Sejenis unsur kimia yang digunakan untuk membunuh serangga yang terdiri dari unsur-unsur berikut:

1) Nitrogen oksida, yaitu unsur kimia yang dapat mengganggu saluran pernafasan, bahkan merangsang terjadinya kerusakan dan perubahan kulit tubuh.

2) Ammonium karbonat, yakni zat yang bias membentuk plak kuning pada permukaan lidah, serta mengganggu kelenjar makanan dan perasa yang terdapat pada permukaan lidah.

e. Amonia

Amonia merupakan gas tidak berwarna yang terdiri dari nitrogen dan hidrogen. Amonia sangat mudah memasuki sel-sel tubuh. Saking kerasnya racun yang terdapat dalam zat ini, sehingga jika disuntikkan sedikit saja kedalam tubuh dapat menyebabkan seseorang pingsan.

f. Formic Acid

Formic acid tidaklah berwarna, bias bergerak bebas, dan dapat mengakibatkan lepuh. Bertambahnya zat ini dalam peredaran darah akan mengakibatkan pernafasan menjadi cepat.

g. Acrolein

Acrolein merupakan sejenis zat tidak berwarna, sebagaimana aldehid. Zat ini diperoleh dengan cara mengambil cairan dari gliserol menggunakan metode pengeringan. Cairan ini sangat mengganggu kesehatan.

h. Hydrogen Cyanide

Hydrogen cyanide merupakan sejenis gas yang tidak berwarna, tidak berbau, dan tidak berasa. Zat ini termasuk zat yang paling 
ringan, mudah terbakar, dan sangat efisien untuk menghalangi pernafasan. Cyanide adalah salah satu zat yang mengandung racun sangat berbahaya.

i. Nitrous Oksida

Nitrous oksida ialah sejenis gas tidak berwarna. Jika gas ini terhisap maka dapat menimbulkan rasa sakit.

j. Formaldehyde

Zat ini banyak digunakan sebagai pengawet dalam laboratorium (formalin).

k. Phenol

Phenol merupakan campuran yang terdiri dari Kristal yang dihasilkan dari destilasi beberapa zat organik, seperti kayu dan arang. Phenol terikat pada protein dan menghalani aktivitas enzim.

I. Acetol

Hasil pemanasan aldehyde (sejenis zat tidak berwarna yang bebas bergerak) dan mudah menguap dengan alcohol.

m. Hydrogen Sulfide

Hydrogen sulfide merupakan sejenis gas beracun yang gampang terbakar dengan bau yang keras. Zat ini menghalangi oksidasi enzim (zat besi yang berisi pigmen).

n. Pyridine

Cairan tidak berwarna dengan bau yang tajam. Zat ini dapat digunakan untuk mengubah sifat alcohol sebagai pelarut dan pembunuh hama.

o. Methyl Chloride

Methyl chloride adalah campuran dari zat-zata bervalensi satu, yang unsure-unsur utamanya berupa hydrogen dan karbon. Zat ini merupakan compound yang sangat beracun.

p. Methanol

Methanol merupakan sejenis cairan ringan yang mudah menguap dan terbakar. Methanol dapat menyebabkan kebutaan, bahkan kematian ${ }^{1}$. 


\section{Paparan Asap Rokok}

Pengaruh rokok terhadap kehamilan sangat serius. Rokok dapat mengurangi aliran darah ke plasenta sehingga berisiko menimbulkan gangguan pertumbuhan janin. Rokok juga dapat meningkatkan risiko keguguran, berat badan bayi rendah, dan gangguan saluran pada nafas bayi.

Salah satu hasil penelitian yang dilakukan di RSU Anutapura Palu didapatkan hasil responden yang terkena paparan asap rokok pada saat hamil berisiko 2,219 kali lebih besar untuk mengalami BBLR dibandingkan responden yang tidak terkena paparan asap rokok pada saat hamil. Karena berdasarkan hasil wawancara sendiri sebagian anggota keluarga responden, pada saat merokok berada didekat ibu atau merokok didalam rumah dan lebih dari satu batang per harinya. yang dimana semakin lama ibu hamil bersama perokok aktif didalam rumah dan ibu terpapar asap rokok $>7$ jam setiap harinya akan berisiko tinggi melahirkan bayi dengan berat badan lahir rendah ${ }^{2}$.

\section{Tinjauan Tentang Faktor Risiko Berat Plasenta}

Berat plasenta berhubungan dengan beberapa faktor penting dan kelahiran neonatus. Berat plasenta merupakan suatu peringatan yang terkait dengan pertumbuhan plasenta selama kehamilan. Faktor-faktor yang berhubungan dengan berat plasenta yaitu usia, paritas, penyakit, pendapatan, status nutrisi, merokok ${ }^{1}$.

Asap rokok berdampak pada pertumbuhan janin oleh karena beberapa bahan rokok seperti nikotin, $\mathrm{CO}_{2}$ dan polycyclic aroamatic hydrocarbons diketahui dapat menembus plasenta yang dapat mempengaruhi terganggunya fungsi plasenta. Lingkungan berasap tembakau mengandung lebih dari 4000 senyawa kimia. Tiga komponen toksik yang utama adalah karbonmonoksida (CO), nikotin (C10H14N2), dan tar. Paparan asap pembakaran tembakau juga menurunkan $20 \%$ kadar asam folat di dalam tubuh, sehingga paparan asap tembakau 
pada ibu hamil menyebabkan gangguan pertumbuhan plasenta dan janin di dalam kandungan ${ }^{2,3}$.

\section{Tinjauan Tentang Keterpaparan Rokok Terhadap Berat Plasenta}

Plasenta adalah organ yang paling penting antara ibu dan janin selama periode prenatal yang juga memiliki kemungkinan terkena efek toksik dari kandungan nikotin dalam rokok. Terpapar asap tembakau secara kronis pada awal kehamilan dapat mempengaruhi perkembangan plasenta baik secara langsung atau tidak langsung dengan mengurangi aliran darah sehingga menciptakan hipoksia patologis di daerah plasenta. Terdapatnya kandungan kadmium dalam jaringan plasenta menunjukkan komponen asap tembakau yang dihisap akan mencapai plasenta yang menyebabkan perubahan panjang diameter kapiler yang berdampak pada berat plasenta ${ }^{2}$.

Perokok pasif adalah penduduk yang bukan perokok, namun tinggal serumah dengan perokok aktif yang merokok di dalam rumah atau terpapar asap rokok ketika mereka berada di wilayah udara yang sama seperti perokok. Sebuah studi menunjukkan bahwa konsentrasi racun ini ditemukan lebih tinggi pada mereka yang terpapar asap tembakau (perokok pasif) daripada mereka dalam asap arus utama (perokok aktif). Asap tembakau yang dihirup oleh perokok pasif mengakibatkan efek yang sangat buruk, selain merugikan pada sistem pernapasan dan kardiovaskular pada ibu hamil, juga dapat mempengaruhi jaringan plasenta langsung maupun tidak langsung dengan menyebabkan vasokonstriksi pembuluh darah pada ibu hamil ${ }^{4}$.

Hasil penelitian membuktikan bahwa sebatang rokok mengakibatkan terjadinya abrupsi, tali pusat mengecil, menurunkan aliran darah sampai lima belas menit. Plasenta pada ibu perokok juga menunjukkan kerusakan pembuluh darah, seperti mengurangi jumlah kapiler dari tempat plasenta. Semakin tingginya pajanan asap rokok memberi kontribusi pada efek akumulasi kandungan nikotin dalam darah, sehingga kelancaran transport nutrisi dan $\mathrm{O}_{2}$ mengalami 
gangguan dan kebutuhan nutrisi dan $\mathrm{O}_{2}$ bagi janin untuk tumbuh akan mengalami perlambatan yang berdampak pada BBLR ${ }^{1}$.

Hasil penelitian diperoleh bahwa keterpaparan rokok merupakan faktor risiko berat plasenta. Hasil uji statistik diperoleh nilai OR $(3,450)$ lebih besar dari 1, ini berarti keterpaparan rokok merupakan faktor risiko berat plasenta ringan, atau ibu yang terpapar asap rokok berisiko 3,450 kali lebih besar mengalami berat plasenta ringan dibanding ibu yang tidak terpapar asap rokok.Upaya mencegah berat plasenta ringan pada ibu hamil dengan penyuluhan rutin pada seluruh lapisan masyarakat tentang bahaya senyawa racun yang terkandung pada asap tembakau terhadap kesehatan khususnya bagi ibu hamil dan seharusnya ibu hamil menghindari asap rokok serta suami perokok segera berhenti merokok ${ }^{1}$. 


\section{DAFTAR PUSTAKA}

1. Andrianasti Preputri (2017). Faktor Risiko Paparan Asap Rokok Terhadap Kejadian Berat Bayi Lahir Rendah Di Kota Makassar. Penelitian Program Pascasarjana Universitas Hasanuddin, Agustus 2017. 27-37 diakses pada tanggal 11 Oktober 2019.

2. A. Fahira Nur (2018). Risiko Paparan Asap Rokok, Ketuban Pecah Dini Dan Plasenta Ringan Terhadap Bblr Di Rsu Anutapura Palu. Jurnal Kesehatan Tadulako Vol. 4 No. 3, Oktober 2018. 1-78. http://jurnal.untad.ac.id/jurnal/index.php/HealthyTadulako/article/view/1 2617/9760 diakses pada tanggall 11 Oktober 2019.

3. Supriyatiningsih (2014). Pengetahuan Obstetri dan Ginekologi untuk Pendidikan Profesi Dokter di Fakultas Kedokteran dan IImu Kesehatan Universitas Muhammadiyah Yogyakarta diakses pada tanggal 11 Oktober 2019. 